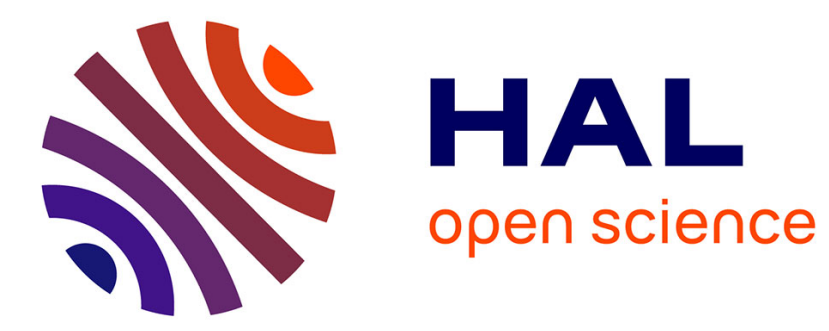

\title{
Explaining Regional Export Performance in a Developing Country: The Role of Geography and Relative Factor Endowments
}

Wim Naude, Thomas Gries

\section{- To cite this version:}

Wim Naude, Thomas Gries. Explaining Regional Export Performance in a Developing Country: The Role of Geography and Relative Factor Endowments. Regional Studies, 2009, 43 (07), pp.967-979. 10.1080/00343400801932300 . hal-00516199

\section{HAL Id: hal-00516199 \\ https://hal.science/hal-00516199}

Submitted on 9 Sep 2010

HAL is a multi-disciplinary open access archive for the deposit and dissemination of scientific research documents, whether they are published or not. The documents may come from teaching and research institutions in France or abroad, or from public or private research centers.
L'archive ouverte pluridisciplinaire HAL, est destinée au dépôt et à la diffusion de documents scientifiques de niveau recherche, publiés ou non, émanant des établissements d'enseignement et de recherche français ou étrangers, des laboratoires publics ou privés. 


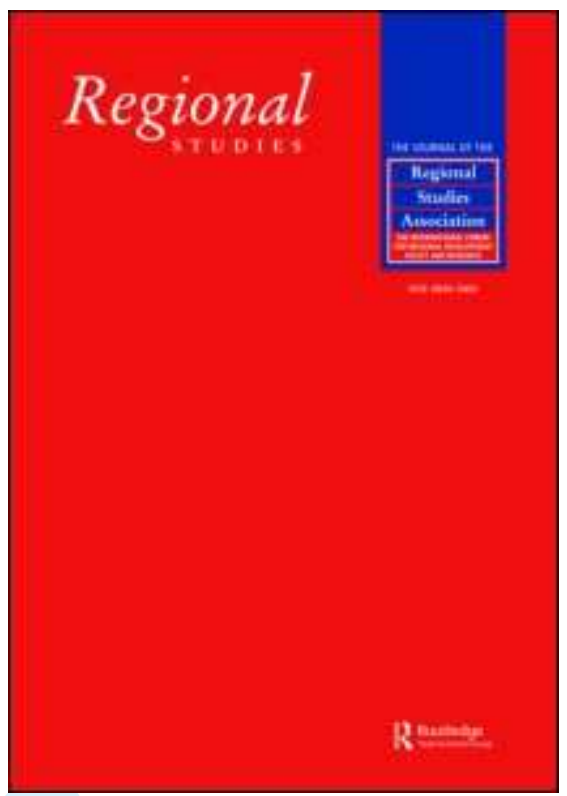

\section{Explaining Regional Export Performance in a Developing Country: The Role of Geography and Relative Factor Endowments}

\begin{tabular}{|r|l|}
\hline Journal: & Regional Studies \\
\hline Manuscript ID: & CRES-2007-0034.R2 \\
\hline Manuscript Type: & Main Section \\
\hline JEL codes: & $\begin{array}{l}\text { R12 - Size and Spatial Distributions of Regional Economic Activity }< \\
\text { Economics, R15 - Econometric and Input-Output Models|Other } \\
\text { Models < R1 - General Regional Economics < R - Urban, Rural, and } \\
\text { Regional Economics }\end{array}$ \\
\hline \hline Keywords: & Exports, Africa, geographical economics \\
\hline
\end{tabular}

\section{SCHOLARONE Manuscripts}




\title{
Explaining Regional Export Performance in a Developing Country: The Role of Geography and Relative Factor Endowments
}

\author{
Wim Naudé* and Thomas Gries** \\ *World Institute for Development Economics Research, United Nations University, Helsinki, \\ Finland and WorkWell, North-West University, Potchefstroom, South Africa, email: \\ naude@wider.unu.edu \\ ** Department of Economics, University of Paderborn, Paderborn, Germany, \\ Thomas_Gries@notes.uni-paderborn.de
}

First received: $\mathrm{Feb} 07$

Accepted: November 07

\begin{abstract}
In this paper we investigate the role of geography in explaining trade. We estimate and contrast two models, a so-called "Skills-to-Land Heckscher Ohlin Model" following Wood and Berge (1997) and a "Geography Hecksher-Ohlin-Von Thünen model" following Redding and Venables (2003). Using panel data across 354 South African magisterial districts over the period 1996 to 2000 we find that only 22 magisterial districts in South Africa is responsible for $85 \%$ of the country's manufacturing exports. While the geography model (with distance, market effects, fixed costs and institutions) offers an overall better explanation for the manufactured export performance of the country's magisterial districts, we also find evidence to support the Skills-toLand Heckscher-Ohlin model. The empirical evidence suggest that regions that are larger in terms of economic size, with good foreign market access and know-how of foreign markets, with competitive transport costs, good local institutions and higher proportions of skilled workers, will be more successful in exporting manufactured goods.
\end{abstract}

Key words: Economic geography, exports, spatial economic development, panel data econometrics, Africa

http://mc.manuscriptcentral.com/cres Email: regional.studies@fm.ru.nl 
JEL Classification numbers: O55, C33, R12, R15

\section{Expliquer les performances régionales à l'exportation dans un pays en développement : le rôle de la géographie et la dotation relative en facteurs Wim Naudé et Thomas Gries}

Résumé : Dans cet article, nous analysons le rôle de la géographie pour expliquer les échanges. Nous évaluons et nous comparons deux modèles, le modèle Heckscher-Ohlin dit d'autarcie et le modèle géographique HeckscherOhlin-Von Thünen. Nous appuyant sur des données portant sur 354 districts judiciaires d'Afrique du Sud pour la période 1996 -- 2000, nous constatons que seulement 22 de ces districts sont responsables de $85 \%$ des exportations manufacturières du pays. Alors que le modèle géographique (avec les distances, les effets du marché, les coûts fixes et les institutions) offre une meilleure explication globale des performances des exportations de produits manufacturés des districts judiciaires du pays ; nous apportons également la preuve en faveur du modèle "autarcie" Hecksher-Ohlin. L'évidence empirique suggère que des régions qui sont plus importantes en termes de taille économique, avec un bon accès aux marchés étrangers et la connaissance de ces derniers, avec des coûts de transport compétitifs, de bonnes institutions locales et une plus forte proportion de main-d'œuvre qualifiée, réussiront mieux en matière d'exportation de biens manufacturés.

Mots-clés : géographie économique, exportations, développement économique spatial, économétrie des données d'échantillons, Afrique.

Classement JEL : O55, C33, R12, R15

Erläuterung von regionaler Exportleistung in einem Entwicklungsland: die Rolle von Geografie und relativen Faktorgegebenheiten

Wim Naudé and Thomas Gries 
Abstract.

In diesem Beitrag untersuchen wir die Rolle der Geografie zur Erklärung von Handel. Wir schätzen und kontrastieren zwei Modelle: ein sogenanntes 'Skills-toLand'-Heckscher-Ohlin-Modell und ein geografisches Heckscher-Ohlin-VonThünen-Modell. Anhand der Paneldaten von 354 südafrikanischen Verwaltungsbezirken im Zeitraum von 1996 bis 2000 stellen wir fest, dass nur 22 Verwaltungsbezirke in Südafrika für $85 \%$ der Produktionsexporte des Landes verantwortlich sind. Obwohl das Geografiemodell (mit Entfernung, Markteffekten, Festkosten und Institutionen) insgesamt eine bessere Erklärung für die Produktionsexportleistung der Verwaltungsbezirke des Landes bietet, finden wir auch Belege zur Unterstützung des 'Skills-to-Land'-Heckscher-Ohlin-Modells. Die empirischen Belege lassen darauf schließen, dass Regionen mehr Erfolg beim Export von Produktionsgütern haben, wenn sie in wirtschaftlicher Hinsicht größer ausfallen, über einen guten Zugang zu Auslandsmärkten und das entsprechende Know-how hierfür verfügen, konkurrenzfähige Transportkosten haben, gute lokale Institutionen aufweisen und über einen höheren Anteil an Facharbeitern verfügen.

Key words:

Wirtschaftsgeografie

Exporte

Räumliche Wirtschaftsentwicklung

Paneldaten-Ökonometrie

Afrika

JEL Classification numbers: O55, C33, R12, R15

Explicando el desempeño de las exportaciones regionales en un país en desarrollo: el papel de la geografía y dotaciones de factores relativos Wim Naudé and Thomas Gries

\begin{abstract}
.
En este artículo investigamos el rol de la geografía a través del comercio. Calculamos y contrastamos dos modelos: el llamado modelo Skills-to-Land Heckscher Ohlin y el modelo de geografía Heckscher Ohlin Von Thünen. Con ayuda de datos de panel en 354 distritos magisteriales de Sudáfrica en un periodo de 1996 a 2000, observamos que sólo 22 distritos magisteriales en Sudáfrica son responsables del $85 \%$ de las exportaciones manufactureras del país. Mientras que el modelo geográfico (con efectos de distancia, mercado, costes fijos e instituciones) ofrece una mejor explicación general para el desempeño de exportación manufacturera de los distritos magisteriales del país, también observamos evidencias que respaldan el modelo Skills-to-Land Heckscher-Ohlin. La evidencia empírica indica que las regiones tendrán más éxito a la hora de exportar mercancías manufacturadas si son mayores en términos de tamaño económico, tienen buen acceso a mercados extranjeros y conocimientos de tales mercados y pueden ofrecer costes competitivos de
\end{abstract}


transporte, buenas instituciones locales y porcentajes más altos de trabajadores cualificados.

Key words:

Geografía económica

Exportaciones

Desarrollo económico espacial

Factores econométricos de datos del panel

África

JEL Classification numbers: O55, C33, R12, R15

\section{INTRODUCTION}

There is a widespread belief in the economic literature that exporting manufactures may be good for economic growth and development. Indeed in many African countries, lack of sufficient manufactured exports are often seen as a major reason for the continent's lack of industrialisation and resulting dismal growth performance. Söderbom and Teal (2001) suggested that "The poor performance of manufacturing in most African countries is arguably due to its inability to export its products".

As a consequence moves trade policies to support export growth have become common in Africa (Elbadawi, 1998). South Africa, with the largest manufacturing sector on the continent, is a case in point (Naudé, Oostendorp \& Serumaga-Zake, 2002; 2005). Since 1994 the country has significantly liberalised its economy through tariff reductions (under the WTO) and the conclusion of a number of free trade agreements (Coetzee, et al, 1997; Naudé \& Coetzee, 2004). 
On a macro-economic level, South Africa's trade liberation and economic reforms since 1994 certainly seems to have contributed towards increased exports of manufactures from the country. For instance, between 1996 and 2000 South Africa's total exports increased on average by $6.7 \%$ per annum. Manufactured exports increased at an even faster rate, of $9.2 \%$ per annum over this period. As a result, the share of manufacturing in total exports increased from $67.5 \%$ in 1996 to $73 \%$ in 2000 .

Simultaneous with trade liberalisation the South African government started to address the spatial economic imbalances created by decades of apartheid policies. This was done through significant changes to the system of local government and other policies such as the creation of "Spatial Development Initiatives" and "Industrial Development Zones" (see e.g. Naudé, 2003; Naudé, Kleynhans \& Van der Merwe, 2003). There seems however, to have been less success in addressing spatial imbalances in the South African economy. For instance Rogerson (1998) expressed concern about the spatial implications of South Africa's export-orientation and Naudé \& Krugell (2003; 2006) failed to found any significant empirical evidence of convergence in per capita incomes across 354 magisterial districts in South Africa since 1994.

Greater exports of manufactured goods may therefore have a differential spatial impact across South Africa, with not all regions or localities being able use 
the opportunities created by trade liberalisation to export more manufactures. If regions or localities benefit in an unequal manner from trade liberalisation it may result in increased spatial imbalances.

The central questions that this paper therefore seeks to address is: how did the various sub-national regions in South Africa benefit from rising manufacturing exports ${ }^{\mathrm{i}}$ since 1994, and what factors determines the differential manufacturing export performance of South Africa's sub-national regions?

The paper is structured as follows. Section two provides a spatial profile of manufactured exports from South Africa. Section three sets out the modelling approach and section four contains the regression results. Section five concludes.

\section{A SPATIAL PROFILE OF MANUFACTURED EXPORTS FROM}

\section{SOUTH AFRICA}

\subsection{Overall Manufactured Exports}

As was mentioned in the introduction, between 1996 and 2000 South Africa's total exports increased on average by $6.7 \%$ per annum. Manufactured exports increased at an even faster rate, of $9.2 \%$ per annum over this period. As a result, the share of manufacturing in total exports increased from $67.5 \%$ in 1996 to $73 \%$ in 2000. Over the same period, Gross Domestic Product (GDP) in South Africa 
grew on average by $2.32 \%$ per annum. Table 1 summarizes the overall situation over the period of this study. (INSERT TABLE 1 ABOUT HERE)

As shown in Table 1 the period between 1996 and 2000 saw significant growth in manufactured exports from South Africa, a growth in the share of manufacturing in total exports, as well as positive overall GDP growth (the decline in manufacturing exports between 1996 and 1997 perhaps reflects the adverse impact of the Asian Crisis). The period also saw a significant depreciation in the Rand:Dollar exchange rate, from an average annual value of R4.29 per USA \$ in 1996 to R6.93 per USA \$ in 2000. This comes down to an annual average depreciation of almost 13\% between 1996 and 2000. This improved price competitiveness of South African contributed to the rapid growth in manufactured exports from the country. Over the same period, the London gold price declined from USA \$ 387.71 to USA \$ 279.08 (a 28\% decline) per ounce, reducing gold production and exports and assisting in the increased share of manufacturing in total exports. By 2000 manufactured exports as percentage of GDP in South Africa had risen to $18.18 \%$ from $14.2 \%$ in 1996.

\subsection{Geographic Concentration of Manufactured Exports}


What were the spatial implications of this good growth in manufactured exports in South Africa? First, it should be noted that most places in South Africa export very little manufactured goods, if at all. Of the 354 magisterial districts only 208 recorded positive manufactured exports in 2000, with 146 districts that exported no manufactured goods. However, compared to 1996, more magisterial districts had entered export markets by 2000, as 167 districts recorded zero exports in 1996 and 187 that did export. Subsequent to the country's internationalisation and internal integration, we therefore find a larger proportion of districts that had entered the market for manufactured exports.

Despite this greater geographical participation in exports, it remains that in 2000 just 22 magisterial districts generated 84\% of South Africa's total exports of manufactures (in 1996 these places generated 85\% of manufacturing exports). About 40 per cent of all manufactured exports originate from the central Johannesburg-Pretoria region (see Naudé and Krugell 2006; Gries and Naudé 2007).

Figure 1 depicts the spatial location of the magisterial districts that export manufactured goods. The shaded districts are those that have positive manufactured exports. The relative volume of exports is indicated according to the percentage of exports from a particular district. For instance, the areas 
shaded black are areas where the district contributes more than 1 per cent of total manufactured exports and the areas shaded grey between 0.1 and 0.99 per cent.

\section{(INSERT FIGURE 1 ABOUT HERE)}

It is evident that the majority of manufactured exports originate in districts in or close to one of the major export hubs, namely City Deep (situated in Johannesburg), Durban harbour (situated in KwaZulu-Natal), Port Elizabeth (situated in the Eastern Cape) and Cape Town harbour (situated in the Western Cape). City Deep is a 'dry' port situated in Johannesburg constructed to cope with container traffic originating from Gauteng. Durban is the largest general cargo port in South Africa and also the best-equipped container terminal. Port Elizabeth is situated midway between the ports of Durban and Cape Town. This port specialises in cargoes for the vehicle manufacturing and vehicle components industries. Cape Town's container terminal is a well-located hub for exports and handles high value and time-sensitive cargoes (Transnet 2006).

From the above it is clear that an important empirical feature of the distribution of the geographical origin of manufacturing exports in South Africa is that there are many magisterial districts with firms that choose not to export at all. The question that is pertinent here is why would some locations (magisterial 
districts in the present case) apparently not be profitable locations from which to export?

Medin (2003) argues the case for fixed costs in exporting which makes exporting profitable for only a selection of firms. Jean (2002) argues that a source of such fixed costs may be 'productivity-enhancement' (e.g. R\&D, foreign networks, knowledge and intelligence, as well as firm-size). From this follows that we ought to see exports of manufactured goods only from localities where productivity is above a certain threshold, and also to observe localities with higher productivity to be able to export more. Empirical evidence supports the implied causality from higher productivity to entry into export markets. For example Fafchamps et al (2002) found that in Morocco firms that were more productive self-selected into exporting. Medin (2003) recognizes that because of the existence of fixed export costs, the decision to export is 'independent of the decision to produce'.

The main 22 origins of South Africa's manufactured exports are summarized in Table 2.

(INSERT TABLE 2 ABOUT HERE) 
From Table 2 it can be seen that South Africa's manufactured exports are geographically concentrated in about 22 places that each contribute at least $1 \%$ of total manufactured exports. Even within these 22 places, the urban agglomeration in South Africa's Gauteng Province, consisting of Johannesburg, Randburg, Boksburg, Germiston and Kempton Park is responsible for no less than $32.73 \%$ of the country's overall manufactured exports in $2000^{\mathrm{ii}}$. Other urban agglomerations also contribute significantly: the Durban-Pietermaritzburg agglomeration is responsible for $11.32 \%$ of South Africa's manufactured exports, the Cape Town - Belville area for $5.98 \%$ and the Pretoria-Brits agglomeration for $7.9 \%$ of all manufactured exports. None of these places, with the possible exception of Uitenhage near Port Elizabeth where the car manufacturer Volkswagen produces for the export market, are in any way rural. Manufactured exports in South Africa are thus predominantly an urban activity.

Table 2 above compares the geographic distribution of manufactured exports between 1996 and 2000. From the totals, it appears as if there was a slight decline in the geographic concentration of manufactured exports between 1996 and 2000 (from the 22 places producing 85.17\% of manufactured exports in 1996 to $83.85 \%$ in 2000 ). A number of significant changes are apparent such as the decline in Johannesburg's manufactured export proportion from $23 \%$ to $18 \%$, but the sharp increases in the manufactured export shares of Cape Town (from 2.7\% 
to $4.7 \%$ ) and Pretoria (from $4.6 \%$ to $7.29 \%$ ). The effect of the Saldanha Steel project in the magisterial district of Vredenburg is also apparent. The expansion in motor vehicle export production in the Eastern Cape has had a positive impact on the manufacturing export shares of Port Elizabeth and Uitenhage.

\subsection{Geographic Specialisation in Manufactured Exports}

In the previous section we provided an overview of the geographic spread of South Africa's manufactured exports. Another dimension of the spatial patterns of exporting is the degree to which different areas specialize in a particular export. In general, we find that most types of manufactured exports tend to originate from "clusters". The Table 3 identifies the geographic clusters for the various main sub-sectors of manufactured exports in South Africa.

(INSERT TABLE 3 ABOUT HERE) 
In Table 3 we have listed the places in South Africa were $50 \%$ of the exports of a particular manufacturing industry originate from. If one can generalize from the above table, it is that chemicals, textiles and wood exports tend to originate from around coastal areas or cities, whilst metals, electrical components and furniture, all goods used extensively in the domestic market and in mining industry, tend to be located closer to the main sources of demand (i.e. the mining sector) in the interior.

For instance, it can be seen that in case of food and beverages, Durban, Johannesburg (with nearby Randburg) and the Western Cape around Cape Town, Stellenbosch and Paarl (location of South Africa's wine industry) are the main geographical cluster areas. Textile production for export seems to be clustered along the coast, in particular in the Eastern Cape and Western Cape around Port Elizabeth and Cape Town. The wood and paper industries cluster their export production primarily around Umzinto (Pietermaritzburg) and Durban in Kwazulu-Natal, whilst the coastal cities of Durban and Cape Town are the place where fuel and chemical exports cluster. Pretoria and Port Elizabeth is the location/origin of non-metallic mineral product exports as well as of electrical machinery and apparatus, whilst metal product exports are specialized around Johannesburg. In the electronic industry, including medical equipment, export-oriented firms are mainly located in the Pretoria and Randburg area. 
Transport equipment (mainly automotive parts) is clustered around Rosslyn (Pretoria) and Uitenhage. The final category includes the broad sector of furniture and other manufacturing, which consists of diamond cutting and jewellery (the former tend to be located around Johannesburg and the latter has a strong concentration in Kimberley due to the presence of the De Beers diamond producer).

\section{MODELLING APROACH}

\subsection{Model Specification: Variations on Heckscher-Ohlin}

From the current state of theory on the determinants of trade, two broad categories of the determinants of manufactured exports can be identified. These are as follows.

\subsubsection{The Skill-and-Land Heckscher-Ohlin Model}

. The H-O model abstracts from distance (transport costs are assumed to be zero) and sees a region's comparative advantage being determined by relative factor endowments. Thus, the relative labour and capital and their productivity in a particular region will determine the goods exported from that region. Wood 
(1997) and Wood and Berge (1997) adjusts the H-O model to argue that the determinants of manufactured exports are human capital (skilled workers) and natural resource endowments (e.g. availability of land) rather than labour and capital as in the standard H-O model. This is the reason, according to Wood and Berge (1997) why Africa will not succeed in exporting manufactures, because it has a low stock of human capital and high natural resource endowment. Wood and Berge (1997), Wood and Jordan (2001) and Mayer and Wood (2001) finds that the $\mathrm{H}-\mathrm{O}$ model explains a significant part of the variation among countries in the shares of manufactured exports. We will refer to Wood (1997) and Wood and Berge's (1997) extension of the H-O model the "Skill-and-Land HeckscherOhlin model" (Wood \& Berge, 1997:36). In the present paper, we expect to see a greater proportion of manufactured exports (relative to primary exports) from magisterial districts where the skills per worker: land per worker ratio is larger. In this skills-and-land $\mathrm{H}-\mathrm{O}$ model, the prediction is that the proportion of manufactured exports to primary exports will be a positive function of the skills per worker and a negative function of the land per worker. In terms of a regression model this prediction can be tested by estimating equation (1) below:

$$
\ln (X m / X p)_{i}=\alpha_{i}+\beta \ln (\text { skills })_{i}+\delta \ln (\text { land })_{i}+\mu_{i}
$$


Where $\ln (\mathrm{Xm} / \mathrm{Xp})=$ the logarithm of the proportion of manufactured exports to primary exports (also termed the gross export ratio), $\ln ($ skills $)=$ the logarithm of the ratio of skills per worker and $\ln ($ land $)=$ the logarithm of the ratio of land per worker and $\mu_{\mathrm{i}}$ a random error term.

As explained by Wood and Berge (1997:39) we expect $\beta>0$ and $\delta<0$ (because a large endowment of land relative to skilled workers confers a comparative disadvantage on manufacturing relative to primary production.

Comparing the absolute sizes of $\beta$ and $\delta$ can be instructive. If $\beta>|\delta|$ it means that manufacturing must be less labour-intensive than primary production, and vice versa (Wood \& Berge, 1997:39-40).

Using a cross-country dataset on 114 country's for 1989, Wood and Berge (1997:45) finds that equation (1) explains about $57 \%$ of the cross-country variation in gross exports, and that both skills and land enter as significant, with $\hat{\beta}=0.81$ and $\hat{\delta}=-0.69$. Their implications for trade policy are that openness will be good for regions with high skills: land ratios, but not for regions with low skill: land ratios. Applied to the present South African case, we expect therefore that after the trade liberalization that commenced in 1994, that magisterial districts where the skill: land ratio was relatively high, would have succeeded in exporting more manufactures relative to primary products. 


\subsubsection{The Geography Heckscher-Ohlin model}

In recent years, a number of efforts have been made to integrate insights from economic geography with the $\mathrm{H}-\mathrm{O}$ model. Relevant examples for present purposes is the Heckscher-Ohlin-Von Thünen model of by Venables and Limao (2002), the Heckscher-Ohlin-Krugman model described by Davis and Weinstein (2003), the 'canonical Von Thünen model' of Overman et al (2003) and the "gravity" model of Redding and Venables (2004). We will loosely refer to these extensions of the H-O model as the "Geography Heckscher-Ohlin model".

While the skill-and-land $\mathrm{H}-\mathrm{O}$ model brought natural resource endowments such as land into the H-O framework, more explicit recognition of geographic factors, and geography induced factors such as agglomeration ${ }^{1}$ (Warner, 2002), transport (see e.g. Helpman and Krugman, 1985) economies of scale and the size of the home market ${ }^{2}$ (Davis and Weinstein, 2003) have been contained in recent extensions of the H-O model.

The contribution of Krugman (1980) has been influential. Krugman introduced transport costs and increasing returns to scale and illustrated that these will affect the location - and clustering - of firms. For instance with economies of scale in manufacturing, producing more at a single plant would

1 Warner (2002) argues that geography can determine where a city locates. 
lower average cost (Krugman, 1980). However, production in a single location would mean that transport costs will have to be paid to sell output elsewhere. With high transport costs, trade would not take place and production will agglomerate close to where demand is with no trade. With low transport costs, there would also be no trade or agglomeration as production will be spread out. Below a certain level of transport costs, manufacturers will locate closer to larger markets (agglomerate) and trade with the periphery. Generally, products will be exported for which there is a large local market. This is the "home-market effect". In Davis and Weinstein's (2003) extension, market structure (monopolistic competition) and love of variety of products shown by consumers (see Krugman, 1980), enforces the home-market effect - i.e. only regions with a large enough home market for a specific variety of good, characterized by increasing returns to scale production, will be net exporters of that good.

Geography as it influences manufacturing decisions can be studied as first nature geography (e.g. natural resources, climate) and second nature geography (distance). Distance creates transport costs, which significantly determines the location of firms producing for the export market. Natural resource availability in the presence of high transport costs creates incentives for establishment near to crucial inputs. We therefore expect to see a greater proportion of manufactured exports in South Africa's magisterial districts that are closer to 
ports so that transport costs of exports are lower. Geography can also determine market access. Here both foreign market access and internal market size are potentially important determinants of a region's export of manufactured goods. Greater access to foreign markets is expected to increase the proportion of manufactured exports.

Also, where manufactured export goods are characterized by increasing returns in production its production will be located closer to internal markets, and cumulative causation effects might lead to extreme geographical concentration of manufacturing production. It might also lead to larger sized firms who are more likely to export more (Roper \& Love, 2001:9). We therefore expect a larger proportion of manufactured exports from magisterial districts in or close to South Africa's six major urban areas (or magisterial districts with larger populations), as well as a larger proportion of manufactured exports from magisterial districts with greater foreign market access (which can be measured by the degree of imports of manufactured goods into a magisterial district) ${ }^{\mathrm{iii}}$.

\subsubsection{Transaction Costs and Institutional Quality}

Manufactured exports are very transaction intensive - it typically requires intensive support services ( Elbadawi, 1998). Using an index of corruption, length 
of paved roads and the number of fax machines as a proxy for transaction costs, Elbadawi (1998:13) finds in an empirical study of African countries that transaction costs are "the major determinants of manufacturing exports and that investing in reducing these costs generates the highest payoff for the capacity to export manufactures". He cannot find evidence in favour of Wood's (1997) and Wood and Berge's (1997) thesis that relative abundance of natural resources in Africa has made manufactured exports from Africa uncompetitive.

Thus, regional export performance may differ to the extent that institutional and regulatory burdens create a local environment characterized by high transaction cost. To the extent that exporting of manufactures are subject to high fixed costs, firms in an unsupportive environment may find it difficult to overcome these fixed costs, and thus refrain from exporting. In section 3.2 below we proxy transaction costs and institutional capacity by productivity on magisterial level by the capital stock ${ }^{\text {iv }}$ of municipalities. Our expectation at this stage is to find that magisterial districts that are better provided by capital will be exporting more manufactures. 


\subsection{Estimating Equation}

We test the predictions identified in sections 3.1.1 to 3.1.3 by using an estimating equation following Wood and Berge (1997), Mayer and Wood (2001) and Redding and Venables (2004) who apply it to a cross-section of countries. It lends itself readily to adoption in a sub-national context. The general form of the estimating equation is given in (2) below.

$\mathbf{y}_{\mathrm{i}}=\mathrm{f}$ (Skills per labor, land per labor, GVA $\mathrm{i}_{\text {, Population }}, \mathrm{M}_{\mathrm{i}}$, DISTANCE $\mathrm{i}$, (APITALi,

Where $\mathbf{y}_{\mathbf{i}}=$ manufacturing exports from magisterial district $\mathbf{i}$.

Skills per labor $=$ the proportion of workers in a district with a matriculation or higher qualification.

Land per labor $=$ the surface area of a district over the number of workers. $\mathrm{GVA}_{\mathrm{i}}=$ gross value added in district $i$ as a measure of the size of a market. In plant-level studies of export determinants, an inverted U-shape relationship between plant size and exports are often found (e.g. Kumar \& 
Sterlacchini, 1994). It is therefore useful to include GVA squared in the model as well.

Population $_{i}=$ population in district $\mathbf{i}$. Both GVA and POP serves as indicators of the size of the home market/

$M_{i}=$ foreign market access of district $i$. This will be measured by the degree of imports of manufactured goods into a district. The more a region can import, the greater will be its external linkages and knowledge of international markets.

DISTANCE $=$ the distance $($ in $\mathrm{km}$ ) of a district from an international port (airport and/or harbour). This is a proxy for the domestic transport costs of exports.

CAPITALi $=$ the capital stock of the municipalities in district $\mathbf{i}$. This is a proxy for the institutional quality in a specific district.

\subsection{Data}

Data on exports of manufactured goods comes from the South African Revenue Services, and Department of Customs and Excise. When exporting, exporters have to indicate their postal code or street address as part of the export 
documentation. Global Insight Southern Africa mapped these exports by magisterial district ${ }^{\mathrm{v}}$.

Data on the independent variables such as labour, population and skills were obtained from various sources, such as Statistics South Africa's 1996 Census and Global Insight Southern Africa's Regional Economic Focus. The human capital measure is an education measure - the number of people per locality with matriculation and higher. The number of persons in this education category in each magisterial district was first estimated using the 1996 census data. The trend in educational attainment between 1996 and 1999 was estimated from the 1999 October Household Survey and used to interpolate national level educational attainment for the years 1997 and 1998. From 2000 onwards, Labour Force Survey raw data was used to calculate the national trend in educational attainment.

Data on the capital stock of municipalities in 1990 was obtained from Econometrix (Pty) Ltd ${ }^{\mathrm{vi}}$. The distance from each magisterial district to the nearest port was calculated using the South African Explorer software provided by the Municipal Demarcation Board (see www.demarcation.org.za ).

Apart from the distance variable and the capital stock of municipalities, the data covers the period 1996 to 2000. 


\subsection{Estimator}

In this study, we will use panel data, i.e. cross-section data over time, where our cross-section units are 354 magisterial districts across South Africa. We fit a Tobit and Random-Effects (RE) Tobit model. A few brief comments on the modelling strategy are in order.

With panel data, our preferred estimating method is panel data estimator, in this case as will be explained, a Random-Effects (RE) GLS-estimator. We do not use an Ordinary Least Squares (OLS) estimator since it suffers from a number of shortcomings that can be overcome by a RE-estimator. The attraction of a REestimator is that it is able to take into account not only effects of observable variables on exports, but also effects due to unobserved heterogeneity between magisterial districts. We prefer a RE-estimatorvii, as it is here assumed that the unobserved heterogeneity is best characterized as randomly distributed variables. Because the various magisterial districts in South Africa vary extensively in their culture, climate ethnic background and distance from one another we take it to be reasonable to assume that the unobserved differences between them are randomly distributed. We also estimate a standard Tobit model as a further robustness check. 
The theoretically derived equation of Redding and Venables (2004) can be re-written as a RE panel data model in a specific form as follows.

$$
y_{i t}^{*}=x_{i t} \beta_{j}+\mu_{i}+\varepsilon_{i t}
$$

Where $\mathrm{y}^{*}$ it $=$ a latent variable measuring ability and desire of location $\mathrm{i}$ to export manufactured goods from magisterial district $\mathbf{i}$ in period $\mathbf{t}$ (we will alternatively also use the export propensity i.e. exports: gross value added, as dependent variable). Also, $x_{i t}=$ a matrix of explanatory variables as discussed; $\mu_{i}=$ a vector of time-invariant unobservable factors determining exports; and $\varepsilon_{i t}=$ a vector a stochastic disturbances

Often $\mu_{\mathrm{i}}$ and $\varepsilon_{i t}$ is written as a composite error term, which is assumed to be normally distributed. We also assume $\mathrm{E}\left(\mu_{\mathrm{i}} \mu_{\mathrm{j}}\right)=0 ; \mathrm{E}\left(\mu_{\mathrm{i}} \varepsilon_{\mathrm{t}}\right)=0$ and $\mathrm{E}\left(\varepsilon_{i t} \varepsilon_{j t}\right)=0$.

We cannot use the standard Generalized Least Squares (GLS) REestimator in the present case, due to the nature of our dependent variable. As indicated in the previous section, not all magisterial districts exported manufactured goods over the period. Our dependent variable can thus be seen to be censored from below ${ }^{\text {viii }}$. We therefore use the Tobin RE-estimator. 
We can interpret $\mathrm{y}^{*}$ it as a latent variable that represents an unobservable 'index of ability' in a magisterial district to export manufactured goods (see also McPherson et al, 1998:8). Manufactured exports will take on a positive value if this measure is positive. In other words

$$
y_{i t}=\left\{\begin{array}{l}
\mathrm{yit}^{*} \text { if } \mathrm{yit}^{*}>0 \\
0 \text { if } \mathrm{yit}^{*} \leq 0
\end{array}\right.
$$

We can also write (4) as

$$
y_{i t}=\left\{\begin{array}{l}
\beta^{\prime} x_{i t}+\mu_{i}+\varepsilon_{i t} \\
O
\end{array} \text { if } \beta^{\prime} x_{i t}+\mu_{i}+\varepsilon_{i t}\right\rangle o
$$

We implement (5) using tobit and $x$ ttobit in STATA 9.The results are discussed in the next section.

\section{REGRESSION RESULTS}

In Table 4 we set out the results from a static Tobit regression. In the Table we have two columns. Column (1) corresponds to the Skills-and-Land H-O model (see equation 1) and column (2) corresponds to the Redding and Venables (2004) 
model of internal, external geography and institutions. In particular, we can compare column (1) with for instance Mayer and Wood (2001: 11; table 2) and Wood and Berge (1997:45; table 1) and we can compare column (2) with Redding and Venables (2004;table 5).

With respect to column (1) we can see that the coefficients on skills and land enter with the right (expected) sign, but that only the land per worker is significant. The model has poor explanatory power, as witnessed by the low pseudo $\mathrm{R}^{2}$. We also note that the coefficient on land is in absolute values much larger than the coefficient on skills (this also holds in a simple OLS regression) so that the implication is that manufacturing exports in South Africa may be more labour intensive than primary production (which could be the case in light of trends in capital intensity in gold and platinum mining and also commercial agriculture).

(INSERT TABLE 4 ABOUT HERE)

With respect to column (2) in Table 4 we can see that the geography H-O model explains the cross-magisterial variation in manufactured exports much better than the more standard $\mathrm{H}-\mathrm{O}$ model. All the coefficients, expect for population which is insignificant, enters with the right sign. Market access (through GVA) and foreign market access, distance to a port as well as institutional quality is 
highly significant. It can be mentioned that Redding and Venables (2004) also finds population to have a seemingly negative (although insignificant) effect. The finding that coefficient on GVA is substantially smaller than one indicates that large magisterial economies are less open than smaller ones. The coefficient on foreign market access is likewise less than unity so that an increase in foreign market access increases export less than proportionately. Redding and Venables (2004) indicates that is consistent with theory that predicts that an expansion in exports will raise costs and prices (including wages) in the export sector and thereby reduce the supply capacity.

In column (2) of Table 4 the distance to port variable captures the effects of what is termed "internal geography'. It is highly significant and negative, suggesting as was expected that the existence of transport costs will lead increasing returns to scale industries to locate in such a way as to minimize transport costs. Redding and Venables (2004) use a different indicator for internal geography, namely the proportion of population living within $100 \mathrm{~km}$ of the coast or navigable river. They also find that internal geography is significant.

Table 5 sets out the results from a RE Tobit estimator. Again, column (1) contains the results on the Skills-and-Land H-O model and column (2) on the “Geography H-O model. 


\section{(INSERT TABLE 5 ABOUT HERE)}

Using a RE-Tobit estimator results in column (1) in the skills to labour ratio now becoming significant. All the variables in column (1) also enter with the right sign. Now the coefficient on skills to labour is larger than the land to labour coefficient in absolute terms, which is indicative of relatively less labour-intensity in manufactured exports than in primary exports. We obtain relatively similar results when we employ a simple pooled OLS regression. Then, the model in column (1) explain about $41 \%$ of the variation in magisterial exports, and the signs of the two coefficients $\beta$ and $\delta$ in equation (1) is roughly of the same absolute magnitude (respectively 0.606 and 0.602 ) which would again suggest a marginally less labour-intensive manufacturing sector than a primary sector in South Africa.

Overall, the results from the two regressions in column (1) of the two tables above generate mixed conclusions about the relevance of the Skill-to-Land Heckscher-Ohlin model to the South African case. The results would seem to suggest that in magisterial districts endowed with relatively more land per worker, less manufactured to primary exports are traded. However, it is not clear that in the magisterial districts with more skilled labour, necessarily more manufactured exports are traded. To further investigate this relationship, we 
plotted the logarithm of manufactured exports/primary exports against the logarithm of skills/land. The scatter plot is contained in Figure 2. (INSERT FIGURE 2 ABOUT HERE)

Figure 2 seems to reject a simple positive and linear relationship between the log of skills to land and the log of manufactured to primary exports. The figure can usefully compared with that from Wood and Berge (1997:48; figure 2) where a more distinctive and steep positive slope is apparent. Moreover, in Figure 2 the relationship between skills to land and manufactured to primary exports in South Africa seems non-linear: it has an inverted U-shape. Future research could clarify this relationship.

As far as column (2) is concerned the results are broadly similar to that in Table 4 for one obvious difference namely that the coefficient on population is negative and significant. This can be interpreted to indicate that a smaller magisterial economy tends to export less. A similar result is found by Redding and Venables (2004). A second important difference in column (2) above from the previous is that now the coefficient on GVA exceeds unity, suggestion in fact that larger magisterial economies in South Africa are more open than smaller ones, a finding that makes intuitively sense following the descriptive overview in section 2 where the dominance of Durban, Cape Town, Johannesburg and Pretoria in terms of South Africa's manufactured exports was pointed out. 
The results in column (2) of Table 5 further confirms the significance of distance (transport costs), institutional quality (fixed and transaction costs) and foreign market access on regional manufactured exports.

When we ran the regression in column (2) using OLS, we found very similar results and found that the equation explained $59 \%$ of the variation in exports. We also found that the coefficient on GVA exceeds unity, and that population enters negatively.

\section{CONCLUDING REMARKS}

Between 1996 and 2000 South Africa's total exports increased on average by 6.7\% per annum. Manufacturing exports increased at an even faster rate, of $9.2 \%$ per annum over this period. As a result, the share of manufacturing in total exports increased from $67.5 \%$ in 1996 to $73 \%$ in 2000 . The period also saw a significant depreciation in the Rand: Dollar exchange rate, from an average annual value of R4.29 per USA \$ in 1996 to R6.93 per USA \$ in 2000. This comes down to an annual average depreciation of almost 13\% between 1996 and 2000. There is relatively consensus that this improved price competitiveness of South African goods was a cause of the rapid growth in manufactured exports from the country. Over the same period, the London gold price declined from USA \$ 387.71 to USA \$279.08 per ounce (a $28 \%$ decline) reducing gold production and 
exports and assisting in the increased share of manufacturing in total exports. By 2000 manufacturing exports as percentage of GDP in South Africa had risen to $18.18 \%$ from $14.2 \%$ in 1996.

While the increase in manufacturing exports was good for the overall South African economy, it is not apparent that it has been equally good for every sub-national region within the country. For instance, in 2000 just 22 magisterial districts generated $84 \%$ of South Africa's total exports of manufactures. In 2000, about 146 out of 354 magisterial districts exported no manufactures at all. In this light the central questions that this paper seek to address was: how did the various sub-national regions in South Africa benefit from rising manufacturing exports since 1994, and what factors determines the differential manufacturing export performance of South Africa's sub-national regions?

To answer these questions, panel data on 354 magisterial districts over the period 1996 to 2000 was used to estimate the determinants of manufactured exports. The theoretical frame of reference was provided by recent extensions to the Hecksher-Ohlin model in the literature. These extensions allow for the incorporation of geography (natural endowments of land, of distance, of market effects, fixed costs and increasing returns of scale) into trade theory. Two models were estimated: a "Skills-and-Land Heckscher-Ohlin" model (following Wood and Berge, 1997) and a "Geography Heckscher-Ohlin" model (following Redding 
and Venables, 2004). Given that the dependent variable (the log of manufactured exports) is zero in more than a third of the magisterial districts, the appropriate estimation technique was the Tobit estimator (censored regression model). We estimated a Random-Effects (RE) Tobit model using panel data over the period 1996 to 2000.

Our results support the findings elsewhere in the literature that geography (both internal and external) matter for export performance. For instance, Redding and Venables (2004) finds that geography is a significant factor in determining cross-country variation in levels and growth of exports. In SubSahara Africa for instance, about $25 \%$ of poor export performance is due to poor foreign market access (external geography) and $25 \%$ due to poor internal geography (transport costs/distance).

We found that both the Skills and Land H-O model and Geography H-O model explains regional export behaviour in South Africa - in contrast to Redding and Venables (2004) who finds only the geography model to give a good fit. However, the geography model explains more of the variation in manufactured exports across South Africa's magisterial districts. Transport costs, due to distance from ports, were found to have a significant negative effect on exports. Also, market access (through GVA) and foreign market access, as well as institutional quality were also found to be highly significant. The size of a 
magisterial district's population has a negative and significant effect, a result that echoes that of the literature (e.g. Redding and Venables, 2004).

It was also found that the coefficient on GVA exceeds unity, suggesting that larger magisterial economies are more open than smaller ones. In contrast to the domestic market effect, the coefficient on foreign market access was found to be less than unity. This is consistent with theory that predicts that an expansion in exports will raise costs and prices (including wages) in the export sector and thereby reduces the supply capacity.

Regarding the Skill-to-Land Heckscher-Ohlin model we found that although the model explained a smaller part of the variation in exports, the results suggested that in magisterial districts endowed with relatively more land per worker, less manufactured to primary exports are traded. The results suggest that labour intensity in South Africa's manufacturing is marginally less than that in primary production.

To conclude we can state that regions that will be more successful in exporting manufactures will be those that are larger in terms of economic size, with good foreign market access and know-how of foreign markets, that faces competitive transport costs on their exports (and imports), that has a good local institutions and has a relatively skilled workforce. Finally, whilst this imply that there is much that local governments can indeed do to raise the conditions for 
manufactured exports in their jurisdictions, it also implies that spatial inequalities may persist, and in fact that coastal cities would tend to fare better under an outward-oriented trade policy framework such as that of South Africa.

\section{REFERENCES}

COETZEE, Z.R. \& NAUDÉ, W.A. (2004). “Labour market responses to Trade Liberalisation in South Africa: a CGE Analysis", Journal of Policy Modeling,26: 91125.

COETZEE, Z.R., GWARADA, K., NAUDÉ, W.A. \& SWANEPOEL, J. (1997). "Currency depreciation, trade liberalisation and economic development", South African Journal of Economics, 65(2): 165-190.

DAVIS, D.R. \& WEINSTEIN, D.E. (2003). "Market access, Economic Geography and Comparative Advantage: An Empirical Test", Journal of International Economics, 59: 1-23.

ELBADAWI, I.A. (1998). "Can Africa Export Manufactures? The Role of Endowment, Exchange Rates \& Transactions cost", Paper presented at the AERC/ OECD/ IMF Workshop, Johannesburg, 6-7 November 1998.

FAFCHAMPS, M., EL HAMINE, S. \& ZEUFACK, A. (2002). "Learning to Export: Evidence from Moroccan Manufacturing", Discussion Paper, Department of Economics, University of Oxford.

GRIES, T. \& NAUDé, W.A. (2007). Trade and Endogenous Formation of Regions in a Developing Country', Review of Development Economics (forthcoming in 2007).

HELPMAN, E. \& KRUGMAN, P.R. (1985). Market Structure and Foreign Trade. Cambridge MA: The MIT Press.

JEAN, S. (2002). “International Trade and Firms' Heterogeneity under Monopolistic Competition", Open Economics Review, 13: 291-311. 
KLEYNHANS, E.P.J., NAUDé, W.A. \& VAN DER MERWE, S.J. (2003). Spatial Economic Development in South Africa: an Evaluation of the Platinum Spatial Development Initiative, Development Southern Africa, December 20 (5) : 617-632.

KRUGMAN, P. (1980). "Scale Economics, Product Differentiation, and the Pattern of Trade", American Economic Review, 70: 950-959.

KRUGMAN, P. (1991)."Increasing returns and economic geography", Journal of Political Economy, 99 : 183-199.

KUMAR, N. \& SIDDHARTHAN, N.S. (1994). “Technology Firm Size and Export Behavior in Developing Countries", Journal of Development Studies, 32: 288-309.

LIMAO, N. \& VENABLES, A.J. (2001). "Infrastructure, geographical disadvantage and transport costs", World Bank Economic Review, 15: 451-479.

MAYER, J. \& WOOD, A. (2001). "South Asia's Export Structure in a Comparative Perspective", Oxford Development Studies, 29 (1) : 5-29.

McPHERSON, M.A., REDFERN, M.R. \& TIESLAU, M.A. (1998). "A Reexamination of the Linder Hypothesis: A Random-Effects Tobit Approach" Mimeo: Department of Economics, University of North Texas.

MEDIN, H. (2003). "Firms' Export Decisions - fixed trade costs and the size of the Export Market", Journal of International Economics, 61: 225-241.

NAUDé, W.A. (2003). Local Government Transformation in South Africa: Challenges for Local Economic Development in a Globalizing Economy, Africa Insight, April. (vol 33 no 3) : pp. 50-56.

NAUDé, W.A. \& MATTHEE, M. 2007. The geographical location of manufacturing exporters in South Africa, UNU-WIDER Research Paper no.2007/09, World Institute for Development Economics Research, Helsinki, Finland.

NAUDé, W.A., OOSTENDORP, R. \& SERUMAGA-ZAKE, P.A.E. (2002). South African Manufacturing in an African Context: Findings from Firm-Level Surveys, South African Journal of Economics, December, 70 (8), 1247-1272. 
NAUDé, W.A., OOSTENDORP, R. \& SERUMAGA-ZAKE, P.A.E. (2005). Determinants of Manufacturing Exports: Results from a Regional Firm-Level Survey in South Africa, Studies in Economics and Econometrics, 29 ( 2): 107-16.

NAUDé, W.A. \& KRUGELL, W.F. (2003). “An Enquiry into Cities and their Role in Subnational Economic Growth in South Africa", Journal of African Economies, 12(4): 476-499.

NAUDÉ, W.A. \& KRUGELL, W.F. (2006). “Economic Geography and Growth in Africa: The Case of Sub-National Convergence and Divergence in South-Africa", Papers in Regional Science, 85 (3), Aug : $443-457$

OVERMAN, H.G., REDDING, S. \& VENABLES, A.J. (2003). "The Economic Geography of Trade, Production, and Income (In Harrigan, J. \& Choi, K. Eds. The Handbook of International Trade. Blackwells: Oxford. ).

REDDING, S \& VENABLES, A. (2004). "Geography and Export Performance: External Market Access and Internal Supply Capacity" (In Baldwin, R. \& Winters, L.A. eds. Challenges to Globalization. Chicago: University of Chicago Press.).

ROGERSON, C.M. (1988). "Regional development policy in South Africa", Regional Development Dialogue, 9: 228-255.

ROGERSON, C.M. (1998). "Restructuring the post-apartheid space economy", Regional Studies, 32(2): 187-198.

ROPER, S. \& LOVE, J.H. (2001). "The Determinants of Export Performance: Panel Data Evidence for Irish Manufacturing Plants", NIERC Working Paper Series no. 69.

TRANSNET (2006). 'South African Port Operations', www.transnet.co.za, accessed 2 February 2006.

VENABLES, A.J. \& LIMAO, N. (2002). "Geographical disadvantage: a Heckscher-Ohlin Von-Thünen model of international specialization", Journal of International Economics, 58: 239-263.

VERBEEK, M. (2000). A Guide to Modern Econometrics. Chicester: John Wiley. 
WARNER, A.M. (2002). Institutions, Geography, Regions, Countries and the Mobility Bias. CID Working Paper no. 91, Harvard University.

WOOD, A. (1997). "Openness and wage inequality in developing countries: the Latin American Challenge to East Asian conventional wisdom", World Bank Economic Review, 11: 33-57.

WOOD, A. \& BERGE, K. (1997). “Exporting Manufactures: Human Resources, Natural Resources and Trade Policy", Journal of Development Studies, 34: 35-59.

WOOD, A. \& JORDAN, K. (2001). “Why does Zimbawe Export Manufactures and Uganda Not? Econometrics Meet History", Journal of Development Studies, 37 (2): $91-116$. 
Table 1: Export and GDP Growth and Average Annual Nominal Exchange Rate, 19962000

\begin{tabular}{|l|l|l|l|l|}
\hline YEAR & $\begin{array}{l}\text { \%GROWTH IN } \\
\text { TOTAL EXPORTS }\end{array}$ & $\begin{array}{l}\text { \%GROWTH IN } \\
\text { MANUFACTURED } \\
\text { EXPORTS }\end{array}$ & $\begin{array}{l}\text { \% GROWTH IN } \\
\text { GDP }\end{array}$ & $\begin{array}{l}\text { RAND:DOLLAR } \\
\text { EXCHANGE } \\
\text { RATE } \\
\text { DEPRECIATION }\end{array}$ \\
\hline $1996-97$ & $2.19 \%$ & $-4.08 \%$ & $2.66 \%$ & $7.2 \%$ \\
$1997-98$ & $5.67 \%$ & $5.81 \%$ & $1.65 \%$ & $20.1 \%$ \\
$1998-99$ & $2.30 \%$ & $14.45 \%$ & $2.13 \%$ & $10.5 \%$ \\
$1999-2000$ & $16.62 \%$ & $20.53 \%$ & $2.84 \%$ & $13.5 \%$ \\
\hline $\begin{array}{l}\text { Period Average } \\
\text { Change }\end{array}$ & $6.7 \%$ & $9.2 \%$ & $2.32 \%$ & $12.8 \%$ \\
\hline
\end{tabular}

(Source of data: South African Reserve Bank, Quarterly Bulletins) 
Figure 1: Manufactured exports per magisterial district in South Africa, 2000

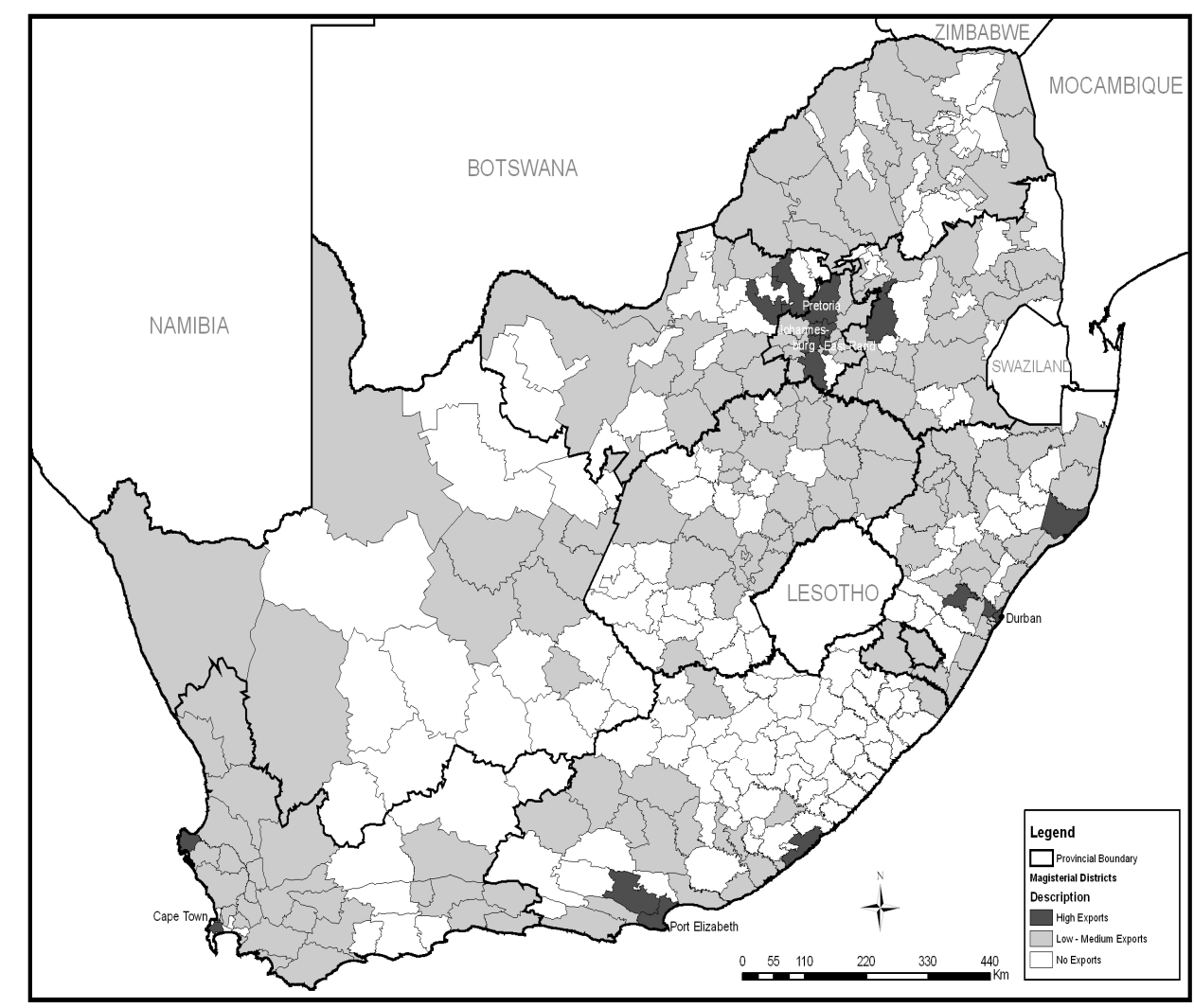

Source: Naudé and Matthee (2007) based on data from South African Customs and Excise Data and Global Insight Southern Africa. 
Table 2: Places Producing $>1 \%$ of South Africa's Total Manufacturing Exports, 1996 and 2000

\begin{tabular}{|l|l|l|}
\hline MAGISTERIAL DISTRICT & $\begin{array}{l}\text { PROPORTION OF TOTAL } \\
\text { MANUFACTURING EXPORTS } \\
\text { IN 1996 }\end{array}$ & $\begin{array}{l}\text { PROPORTION OF TOTAL } \\
\text { MANUFACTURING EXPORTS } \\
\text { IN 2000 }\end{array}$ \\
\hline Belville & $1.35 \%$ & $1.22 \%$ \\
Cape Town & $2.77 \%$ & $4.76 \%$ \\
Wynberg & $0.89 \%$ & $1.08 \%$ \\
Worcester & $1.02 \%$ & $0.25 \%$ \\
Vredenburg & $0.27 \%$ & $1.11 \%$ \\
East London & $0.41 \%$ & $1.60 \%$ \\
Port Elizabeth & $2.43 \%$ & $4.19 \%$ \\
Uitenhage & $0.47 \%$ & $3.42 \%$ \\
Kimberley & $9.95 \%$ & $3.62 \%$ \\
Durban & $9.64 \%$ & $9.70 \%$ \\
Pietermaritzburg & $1.09 \%$ & $1.62 \%$ \\
Umzinto & $0.93 \%$ & $1.33 \%$ \\
Lower Umfolozi & $7.51 \%$ & $7.29 \%$ \\
Rustenburg & $1.06 \%$ & $2.03 \%$ \\
Brits & $1.30 \%$ & $0.69 \%$ \\
Pretoria & $4.64 \%$ & $7.21 \%$ \\
Johannesburg & $23.61 \%$ & $18.77 \%$ \\
Randburg & $5.69 \%$ & $7.25 \%$ \\
Boksburg & $1.00 \%$ & $0.92 \%$ \\
Germiston & $4.45 \%$ & $2.29 \%$ \\
Kempton Park & $3.55 \%$ & $2.52 \%$ \\
Witbank & $1.15 \%$ & $0.98 \%$ \\
\hline TOTAL & $85.17 \%$ & $83.85 \%$ \\
\hline Sorce of & & $5.21 \%$ \\
\hline
\end{tabular}

(Source of data: Global Insight Southern Africa from South African Customs and Excise Data) 
Table 3: Export-oriented Manufacturing Clusters in South Africa, 2000

\begin{tabular}{|c|c|}
\hline MANUFACTURING SECTOR & $\begin{array}{l}\text { PLACE OF GEOGRAPHIC SPECIALISATION (Location } \\
\text { of at least } 50 \% \text { of South African exports of a good) }\end{array}$ \\
\hline Food, beverages and tobacco products & $\begin{array}{l}\text { Durban }(10.9 \%) \text {, Johannesburg }(10.14 \%) \text {, Cape Town } \\
(9.45 \%) \text {, Stellenbosch }(8.20 \%) \text {, Paarl }(6.94 \%) \text {, Randburg } \\
(5.9 \%)\end{array}$ \\
\hline Textiles, clothing and leather goods & $\begin{array}{l}\text { Port Elizabeth }(29.5 \%) \text {, Cape Town }(10.8 \%) \text {, Zwelitsha } \\
(7.43 \%) \text {, Durban }(7.09 \%) \text {. }\end{array}$ \\
\hline Wood, Paper and Printing & Umzinto (19.5\%), Johannesburg (15.9\%), Durban (15.3\%) \\
\hline $\begin{array}{l}\text { Fuel, petroleum, chemical and rubber } \\
\text { products }\end{array}$ & $\begin{array}{l}\text { Durban }(23.3 \%) \text {, Cape Town }(13.22 \%) \text {, Johannesburg } \\
(13.04 \%)\end{array}$ \\
\hline Other non-metallic mineral products & $\begin{array}{l}\text { Pretoria }(27.45 \%) \text {, Port Elizabeth }(14.5 \%) \text {, Johannesburg } \\
(14.15 \%) \text {. }\end{array}$ \\
\hline $\begin{array}{l}\text { Metal products, machinery and household } \\
\text { appliances }\end{array}$ & $\begin{array}{l}\text { Johannesburg (24.23\%), Lower Umfolozi (Richardsbay) } \\
(13.98 \%) \text {, Randburg }(10.48 \%) \text {. }\end{array}$ \\
\hline Electrical machinery and apparatus & $\begin{array}{l}\text { Pretoria }(16.2 \%) \text {, Port Elizabeth }(12.76 \%) \text {, Johannesburg } \\
(10.59 \%) \text {, Randburg }(10.25 \%) \text {, Kempton Park }(5.27 \%) .\end{array}$ \\
\hline $\begin{array}{l}\text { Electronic, sound/vision, medical \& other } \\
\text { appliances }\end{array}$ & Randburg (20.81\%), Pretoria (20.64\%), Inanda (15.43\%). \\
\hline Transport equipment & Pretoria $(26.90 \%)$, Uitenhage $(24.56 \%)$ \\
\hline $\begin{array}{l}\text { Furniture and other items NEC and } \\
\text { recycling (including diamond cutting and } \\
\text { jewellery) }\end{array}$ & $\begin{array}{l}\text { Johannesburg }(28.67 \%) \text {, Kimberley }(14.45 \%) \text {, Pretoria } \\
(7.48 \%) \text {. }\end{array}$ \\
\hline
\end{tabular}


Table 4: Static Tobit Maximum Likelihood Regression Results; Dependent Variable: Logarithm of Export of Manufactured Goods

\begin{tabular}{|l|l|l|}
\hline Variable & \multicolumn{1}{|c|}{ (1) } & \multicolumn{1}{c|}{ (2) } \\
& Skills-and-Land H-O Model & \multicolumn{1}{|c|}{ Geography H-O Model } \\
\hline Intercept & 8.6 & -3.9 \\
& $(2.06)^{* *}$ & $(2.17)^{* *}$ \\
\hline Skills to Labour ratio & 0.15 & \\
& $(0.31)$ & \\
\hline Land to Labour ratio & -1.3 & \\
& $(-6.64)^{* * *}$ & \\
\hline Population & -0.14 & -0.16 \\
& $(-0.36)$ & $(-0.65)$ \\
\hline Gross Value Added & & 0.46 \\
& & $(2.17)^{* *}$ \\
\hline Foreign Market Access & & 0.65 \\
& & $(9.77)^{* * *}$ \\
\hline Distance to Port & -0.40 \\
& & $(-2.58)^{* * *}$ \\
\hline Institutional Quality & & 0.13 \\
& & $(3.03)^{* * *}$ \\
\hline SE & 3.2 & 2.17 \\
\hline Psuedo R2 & 0.09 & 0.21 \\
\hline Log-likelihood & -348.717 & -426.01 \\
\hline Number of observations & 137 & 196 \\
\hline
\end{tabular}

The t-ratio's are in brackets.

${ }^{* *}$ Significance at the $1 \%,{ }^{* *}$ at the $5 \%,{ }^{*}$ and at the $10 \%$ level. 
Table 5: Random Effects Tobit Regression Results: Dependent Variable: Logarithm of Export of Manufactured Goods

\begin{tabular}{|c|c|c|}
\hline Variable & $\begin{array}{c}\text { (1) } \\
\text { Skills-and-Land H-O Model }\end{array}$ & $\begin{array}{c}(2) \\
\text { Geography H-O Model }\end{array}$ \\
\hline Intercept & $\begin{array}{l}-24.57 \\
(-8.17)^{* * *}\end{array}$ & $\begin{array}{l}-17.21 \\
(-5.91)^{* * *}\end{array}$ \\
\hline Skills to Labour ratio & $\begin{array}{l}0.66 \\
(3.46)^{* * *}\end{array}$ & - \\
\hline Land to Labour ratio & $\begin{array}{l}-0.36 \\
(-1.73)^{* *}\end{array}$ & - \\
\hline Population & $\begin{array}{l}3.30 \\
(9.66)^{* * * *}\end{array}$ & $\begin{array}{l}-0.65 \\
(-2.33)^{* *}\end{array}$ \\
\hline Gross Value Added & - & $\begin{array}{l}1.90 \\
(8.79)^{* * *}\end{array}$ \\
\hline Foreign Market Access & - & $\begin{array}{l}0.73 \\
(8.63)^{* * *}\end{array}$ \\
\hline Distance to Port & -9 & $\begin{array}{l}-0.33 \\
(-1.88)^{* *}\end{array}$ \\
\hline Institutional Quality & - & $\begin{array}{l}0.29 \\
(6.71)^{* * *}\end{array}$ \\
\hline $\begin{array}{l}\sigma_{\mu} \\
\sigma_{\varepsilon}\end{array}$ & $\begin{array}{l}5.9 \\
2.7\end{array}$ & $\begin{array}{l}5.3 \\
2.9\end{array}$ \\
\hline Wald $\chi^{2(3)} p$-value & 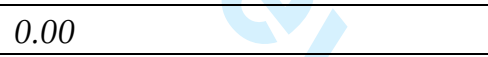 & 0.00 \\
\hline Log-likelihood & 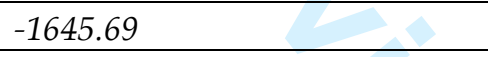 & -2232.21 \\
\hline Number of observations & $\begin{array}{l}688 \\
172\end{array}$ & 911 \\
\hline
\end{tabular}

The z-ratio's are in brackets.

${ }^{* * *}$ Significance at the $1 \%,{ }^{* *}$ at the $5 \%,{ }^{*}$ and at the $10 \%$ level. 
1

2

3

4

5

6

7

8

9

10

11

12

13

14

15

16

17

18

19

20

21

22

23

24

25

26

27

28

29

30

31

32

33

34

35

36

37

38

39

40

41

42

43

44

45

46

47

48

49

50

51

52

53

54

55

56

57

58

59

60
Figure 2 Export structure (manufacturing/primary) and resources by magisterial district in South Africa, 2000

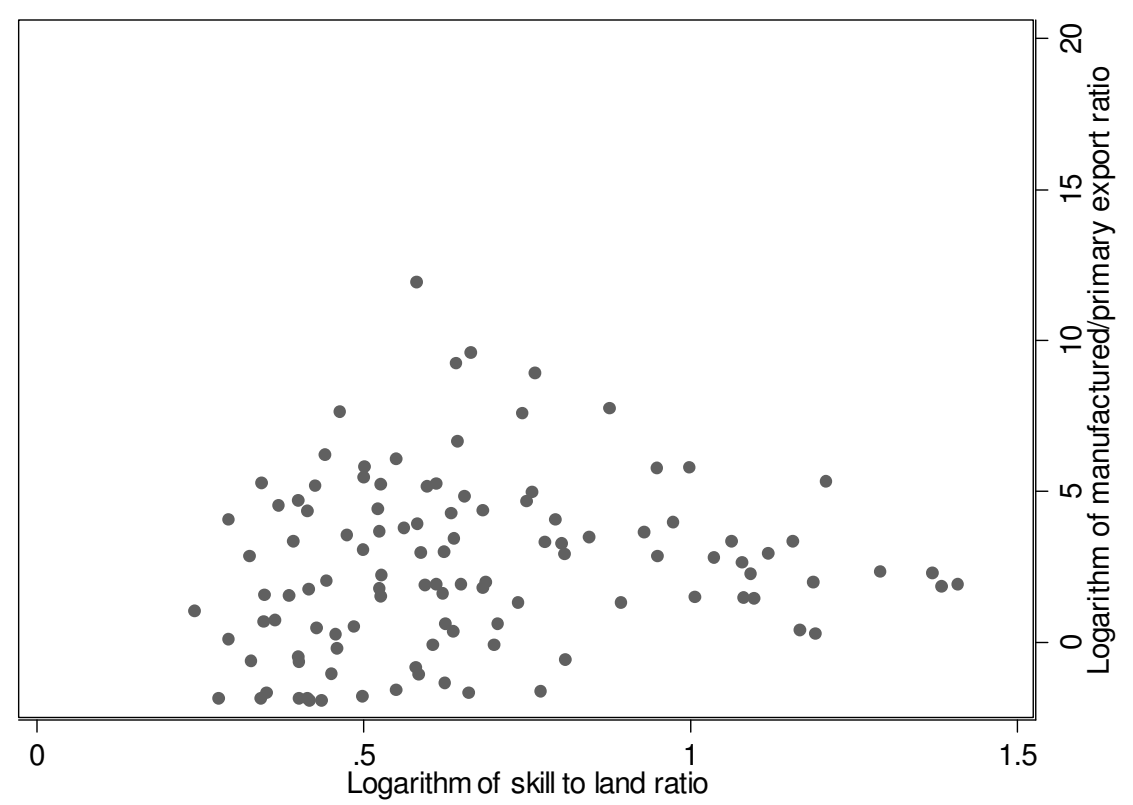




\section{END NOTES}

\footnotetext{
${ }^{\mathrm{i}}$ South Africa is abundant in raw materials with an important primary sector (agriculture and mining). However due to the arguments provided in the introduction for being interested in manufacturing as such, it is also the case that manufacturing firms are more "footloose" in their location than for instance firms in primary production. Whilst foreign earnings from greater manufacturing exports have increased, there has also over the same period being an increase in foreign exchange from non-traditional 'exports' such as tourism.

ii The fact the a significant percentage of South Africa's manufactured exports originates from locations relatively far from the coast (in the case of Gauteng around 500 kilometres) suggests that transportation costs could be an important factor in the overall competitiveness of South Africa's manufactured goods.
}

iii We realise that this proxy may be controversial. It is, however, the only quantifiable measure to reflect possible local knowledge of trade.

${ }^{\text {iv }}$ We use capital stock of municipalities, as this is a good indicator of the capacity and capability of the local government, who has a significant impact in rolling out public infrastructure. Alternatively we also use urban density.

${ }^{v}$ We are grateful to Francois Fouché from Global Insight Southern Africa (Pty) Ltd for assistance with the dataset.

${ }^{\text {vi }}$ We are grateful to Michael Jackson from Econometrix (Pty) Ltd for making available this dataset to us

${ }^{\text {vii }}$ In the present instance a fixed-effects estimator cannot be used as it is not possible to estimate an unbiased Tobit model where the fixed effects can be conditioned out. Unconditional fixed-effects estimates are known to be biased.

viii By excluding all zero export cross section units from our sample will lead to biased and inconsistent parameter estimates (see McPherson et al, 1998:8-9). See also Verbeek (2000:1999). 